\title{
Multilocus Analysis Using Putative Fungal Effectors to Describe a Population of Fusarium oxysporum from Sugar Beet
}

\author{
Paul A. Covey, Brett Kuwitzky, Mia Hanson, and Kimberly M. Webb
}

United States Department of Agriculture-Agricultural Research Service, Sugar Beet Research Unit, 1701 Centre Ave., Fort Collins, CO 80526.

Accepted for publication 29 January 2014.

\section{ABSTRACT}

Covey, P. A., Kuwitzky, B., Hanson, M., and Webb, K. M. 2014. Multilocus analysis using putative fungal effectors to describe a population of Fusarium oxysporum from sugar beet. Phytopathology 104:886-896.

Sugar beet (Beta vulgaris) Fusarium yellows is caused by Fusarium oxysporum $\mathrm{f}$. sp. betae and can lead to significant reductions in root yield, sucrose percentage, juice purity, and storability. F. oxysporum f. sp. betae can be highly variable and many $F$. oxysporum strains isolated from symptomatic sugar beet are nonpathogenic. Identifying pathogenicity factors and their diversity in the $F$. oxysporum $\mathrm{f}$. sp. betae population could further understanding of how this pathogen causes disease and potentially provide molecular markers to rapidly identify pathogenic isolates. This study used several previously described fungal effector genes (Fmk1, Fowl, Pdal, PelA, PelD, Pepl, Prt1, Rhol, Sgel, Sixl, Six6, Snfl, and Ste12) as genetic markers, in a population of 26 pathogenic and nonpathogenic isolates of $F$. oxysporum originally isolated from symptomatic sugar beet. Of the genes investigated, six were present in all F. oxysporum isolates from sugar beet (Fmkl, Fowl, PelA, Rhol, Snfl, and Ste12), and seven were found to be dispersed within the population (Pda1, PelD, Pep1, Prt1, Sge1, Sixl, and Six6). Of these, Fmk1, Fowl, PelA, Rhol, Sgel, Snfl, and Ste12 were significant in relating clade designations and PelD, and Prtl were significant for correlating with pathogenicity in F. oxysporum f. sp. betae.
Fusarium oxysporum strains are common soilborne fungi, many of which cause wilting and root or bulb rot in a wide range of plant species (17). Individual strains of $F$. oxysporum usually infect one of a few host species; therefore, they have been grouped into host-specific forms (formae speciales) based on pathogenicity to a particular plant host species (2). F. oxysporum also contains many nonpathogenic strains, which are very efficient saprophytes of plant tissues but do not cause symptoms on their hosts $(11,17,57,61)$. F . oxysporum is a species complex of morphologically indistinguishable strains $(3,44)$, and isolates of different formae speciales may be more closely related to each other than isolates belonging to the same forma specialis $(39,44$, $61)$. To date, there have been $>120$ formae speciales described $(13,50)$. Currently, the most dependable method to confidently classify strains of $F$. oxysporum to formae speciales is the use of a bioassay, in which putative host plants are exposed to the fungus and are assessed for the development of associated pathogenic symptoms $(2,61)$. Rapid and reliable methods to differentiate pathogenic isolates from nonpathogenic $F$. oxysporum generally are unavailable for all formae speciales (61).

F. oxysporum f. sp. betae $(70,73,74)$ is an important pathogen in sugar beet (Beta vulgaris L.) and is the primary causal agent for Fusarium yellows, which can lead to significant reductions in root yield, sucrose percentage, juice purity, and storability $(4,24$, 74). Fusarium yellows is characterized by interveinal yellowing, chlorosis, wilting and necrosis of the leaves, and a gray to reddish or red-brown discoloration in the vascular tissue of the roots

Corresponding author: K. M. Webb; E-mail address: Kimberly.webb@ars.usda.gov

* The $\boldsymbol{e}$-Xtra logo stands for "electronic extra" and indicates that the online version contains one supplementary table.

http://dx.doi.org/10.1094/PHYTO-09-13-0248-R

This article is in the public domain and not copyrightable. It may be freely reprinted with customary crediting of the source. The American Phytopathological Society, 2014.
$(24,70,74) . F$. oxysporum f. sp. betae can be highly variable in growth, pigmentation, conidia production, and virulence $(22,25$, 70). A complicating factor for the identification of pathogenic $F$. oxysporum f. sp. betae isolates is that a high number of $F$. oxysporum isolates recovered from symptomatic sugar beet are nonpathogenic $(22,70,81)$. Variability of the sugar beet $F$. oxysporum population is increased further by the wide geographic distribution of sugar beet production in the United States, initial diversity of the fungal population, and environmental influences (23-26).

In $F$. oxysporum, many methodologies have been used to characterize phylogenetic relationships and the classification of pathogenicity to a host species $(3,39,55,60,61)$. Many studies characterizing the population structure of fungal pathogens, including $F$. oxysporum, have utilized conserved homologous gene markers (76). The methods that have been used to characterize the genetic diversity and evolutionary origin of $F$. oxysporum $\mathrm{f}$. sp. betae from sugar beet include vegetative compatibility groups $(25,80)$, restriction fragment length polymorphisms (52), random amplified polymorphic DNA (7), and comparisons of DNA sequences from conserved genomic regions $(27,81)$. Although these technologies have been useful in distinguishing F. oxysporum from other Fusarium spp., and have been used to further group strains into some formae speciales $(1,44,55)$, they have been insufficient in describing the regional variation of the population of $F$. oxysporum from sugar beet and are unable to differentiate between pathogenic $F$. oxysporum f. sp. betae and nonpathogenic isolates of $F$. oxysporum $(7,25,27,81)$.

Effector genes are described as genes necessary for disease development but are not necessary for a pathogen to complete its lifecycle in vitro $(28,32)$. Fungal effector genes fall into several classes, including coding for infection structures, cuticle- and cell-wall-degrading enzymes, ability to respond to environmental cues, fungal toxins, signal cascade components, and suppression of plant immunity $(28,32,34)$. Fungal plant pathogens, including F. oxysporum, utilize a wide array of secreted molecules often referred to as elicitors or virulence and avirulence factors $(34,78)$ 
as well as specific genes that encode host-determining factors, which are used to gain access into plants and contribute to disease development in the host $(5,28,71,76)$.

Utilizing these putative effector genes, it is possible to use patterns of nucleotide diversity within and among populations to infer the molecular basis of pathogen relatedness and coevolution with a plant host (76). Stukenbrock and McDonald (75) used the haplotypic diversity of SnToxA in a population of Phaeosphaeria nodorum to support the hypothesis that evolution of the gene is driven by the host. Another example is the study of Rhynchosporium secalis, which causes leaf scald in barley, where the polymorphism of deletion mutations within the avirulence gene $N I P 1$ was used to characterize the population diversity as well as determine whether that particular gene was under corresponding diversifying selection (72). In F. oxysporum, Lievens et al. (43) used the presence of seven secreted-in-xylem (Six) genes to identify and discriminate isolates to the forma specialis of $F$. oxysporum f. sp. lycopersici pathogenic to tomato.

Identifying putative effector genes and their diversity in the $F$. oxysporum f. sp. betae population could lead to further understanding of how this pathogen causes disease on sugar beet, characterize the diversity of the pathogen population, offer genetic markers to identify pathogenic isolates, and, ultimately, provide insight into host susceptibility and resistance. The objectives of this study were to (i) determine the genetic diversity of the $F$. oxysporum population from symptomatic sugar beet using described effector genes and (ii) determine whether this diversity could be associated with the pathogenicity of F. oxysporum f. sp. betae to sugar beet.

\section{MATERIALS AND METHODS}

Fusarium isolates and culture maintenance. F. oxysporum isolates were obtained from the Fusarium long-term culture collection at the United States Department of AgricultureAgricultural Research Service Sugar Beet Research Unit (SBRU) in Fort Collins, CO. Each isolate was originally recovered from a single conidium or via hyphal-tip transfer from original cultures obtained from infected sugar beet, and stored on filter papers at $-20^{\circ} \mathrm{C}$ in the SBRU culture collection using modified protocols described by Fong et al. (14) and Peever and Milgroom (59). Briefly, each isolate was plated onto water agar and sterile glass microfiber filter paper pieces of $\approx 1 \mathrm{~cm}^{2}$ placed equidistant from the point of transfer. Plates were grown at $25^{\circ} \mathrm{C}$ for 10 to 14 days or until the fungus had grown through all paper sections, after which filter paper pieces were removed, placed in sterile paper envelopes, and dried overnight over desiccant in a biocontainment hood $(14,22,59)$. Working cultures of all isolates were maintained on potato dextrose agar (PDA) (Becton, Dickinson and Co., Sparks, MD) grown at $25^{\circ} \mathrm{C}$ for 7 days, then maintained at room temperature, and transferred a maximum of two times using established protocols, as described by Leslie and Summerell (42). In total, 26 isolates were originally isolated from symptomatic sugar beet and represent both pathogenic (F. oxysporum f. sp. betae) and nonpathogenic ( $F$. oxysporum) isolates (Table 1). Pathogenicity for most isolates had been reported previously $(27,81)$. For isolates in which pathogenicity to sugar beet had not been previously described, pathogenicity testing was performed as described by Hanson and Hill (22) and Hanson and Jacobsen (23). All isolates were inoculated on a Fusarium susceptible sugar beet germplasm 'FC716' that had been grown in a greenhouse for 5 weeks and inoculated with prepared inoculum via a root dip assay, as described by Hanson and Hill (22). Plants were rated weekly for Fusarium yellows symptoms for 6 weeks after inoculation using a 0 -to-5 rating scale, as described by Hanson and Jacobsen (23). Selected isolates represented the phylogenetic diversity of each of the three clades found in the United States sugar beet $F$. oxysporum population, as previously described $(27,81)$. Three $F$. oxysporum f. sp. spinaciae isolates
(FUS001, FUS003, and FUS004) originally collected from spinach but that have been reported previously to be pathogenic to sugar beet and characterized to be members of the phylogenetic clade C (27) were also included in this study (Table 1). Two isolates of $F$. proliferatum (F182 and Fob273a) and one isolate of F. avenaceum (F20), all originally isolated from symptomatic sugar beet, were used as outgroup isolates (Table 1). In silico genomic sequences were obtained from 11 additional $F$. oxysporum isolates (FOL4287, HDV247, FOSC3-a, Fo47, MN25, PHW808, PHW815, CL57, II5, NRRL26406, and NRRL25433), 1 F. graminearum isolate (PH-1), and $1 F$. verticillioides isolate (Strain7600) using the comparative genomic sequence datasets available from the BROAD Institute database (http://www.broadinstitute.org/ annotation/genome/fusarium_group/MultiHome.html) (Table 1).

Genomic DNA extractions. $F$. oxysporum cultures were grown in potato dextrose broth (PDB) (Becton, Dickinson and Co.) by inoculating with a 7-mm mycelial plug from a working PDA culture of each isolate. Cultures were grown in the dark for 5 days at $25^{\circ} \mathrm{C}$ on a rotary shaker at $100 \mathrm{rpm}$. Mycelial masses were collected by pouring PDB cultures through sterilized doublelayered cheesecloth, then rinsing the mass five times with sterile distilled water. Mycelial masses were placed into $1.5-\mathrm{ml}$ microcentrifuge tubes which were then frozen by placing the at $-20^{\circ} \mathrm{C}$ for $24 \mathrm{~h}$, and lyophilized at $-50^{\circ} \mathrm{C}$ for $48 \mathrm{~h}$ using a Lyph Lock 4.5 lyophilizer (Labconco Co, Kansas City, MO). Lyophilized tissue was ground using a mortar and pestle and DNA was extracted using the manufacturer's protocol number 3 of a EasyDNA extraction kit (Invitrogen, Carlsbad, CA).

Primer design for putative pathogenicity and virulence effector genes. The DNA sequences of 12 previously reported fungal effector genes and virulence effectors (Fmkl, Fowl, Pdal, PelA, PelD, Pep1, Rho1, Sge1, Sixl, Six6, Snf1, and Ste12) (9,21, $29,33,47,49,58,62,66,67,79)$ were obtained from either the National Center for Biotechnology Information (NCBI) database or the BROAD Institute Fusarium Comparative Genome database. A 13th gene, which we dubbed "Pep-restless like transposon" (Prt1), was based on homology to an open reading frame (ORF4) found on the pea pathogenicity island of $F$. solani (teleomorph Nectria haematococca) which also contains Pep and Pda genes (21). This ORF has similarity to the transposase of the restless transposon of Tolypocladium inflatum (38). Single-gene or multiple-sequence alignments were used to design primers for each gene using the primer design software Primer 3 (69). Specific primer pairs were designed for each gene to eliminate paralogs of gene sequences present in our $F$. oxysporum population (Table 2). Primers previously described by O'Donnell et al. (56) were used to identify sequences of the translation elongation factor 1- $\alpha$ (Tef1- $\alpha)$ gene (Table 2) and used for the phylogenetic analysis to describe clade designation for each isolate. Clade assignments were performed as previously described $(27,81)$.

Genotyping. Polymerase chain reaction (PCR) was carried out in a Mastercycler gradient thermal cycler (Eppendorf, Westbury, NY) using genomic DNA with PCR conditions optimized for each primer combination. PCR conditions consisted of an initial denaturing at $94^{\circ} \mathrm{C}$ for $2 \mathrm{~min}$; followed by 32 cycles of $94^{\circ} \mathrm{C}$ for $45 \mathrm{~s}$, primer-specific annealing temperature (Table 2) for $45 \mathrm{~s}$, and $72^{\circ} \mathrm{C}$ for $45 \mathrm{~s}$; and a final extension step of $72^{\circ} \mathrm{C}$ for $5 \mathrm{~min}$. PCR products were held at $4^{\circ} \mathrm{C}$ until visualized. PCR reactions for each isolate-gene combination were repeated twice. PCR amplicons were visualized on $1.5 \%$ agarose gels stained with ethidium bromide. Single amplicons were directly purified from each PCR reaction, using the GenCatch PCR Cleanup Kit (Epoch, Sugarland, TX). Sequencing was performed by Eurofin, MWG/Operon (Huntsville, AL) and both the $5^{\prime}$ and $3^{\prime}$ primers (Table 2) were used for paired end sequencing for each purified amplicon. Novel gene sequences from sugar beet isolates discovered in this study were submitted to GenBank and are listed in supplemental materials (Supplementary Table 1). 
Data analysis. Sequence alignment and homology. Sequences were first edited by hand using Geneious Software v. 5.5.6 (37) and any ambiguously aligned sequences were not included in subsequent analysis. Multiple sequence alignments were performed using the neighbor-joining clustering algorithm of CLUSTALX 2.1 (40). Consensus nucleotide sequences for each gene were used to search available Fusarium spp. genomes, using the comparative genomic sequences datasets available at the BROAD institute using BLASTn (BLOSUM62). In general, each gene was aligned as a single hit; however, if multiple paralogs were identified, the most similar paralog, based on pairwise analysis (cut-off E-value 1e-3; pairwise identity $[\mathrm{PWI}]>70 \%$ ), was included in the nucleotide sequence alignments and used for subsequent phylogenetic analysis.
Phylogenetics. Phylogenetic analysis was performed on all isolates (including the in silico isolates) using the Tefl- $\alpha$ sequences available from the BROAD Fusarium database. Tefl- $\alpha$ sequence for all isolates were aligned as previously described by Hill et al. (27) and used as input data for generating a phylogentic tree using the MrBayes plugin of Geneious (30). The General Time Reversible substitution model was performed using a $\gamma$-distributed variation consisting of two simultaneous runs with $1,100,000$ generations, a sample frequency of 200, and a burn-in of 110,000 generations, resulting in 4,951 sample trees. All isolates were then assigned to clade using previously reported criteria $(27,81)$.

Phylogenetic analysis was also performed on each gene from all isolates included in the study. Sequences were aligned as previously described and used as input alignment data for gen-

TABLE 1. Description of Fusarium oxysporum isolates used to characterize the population from symptomatic sugar beet

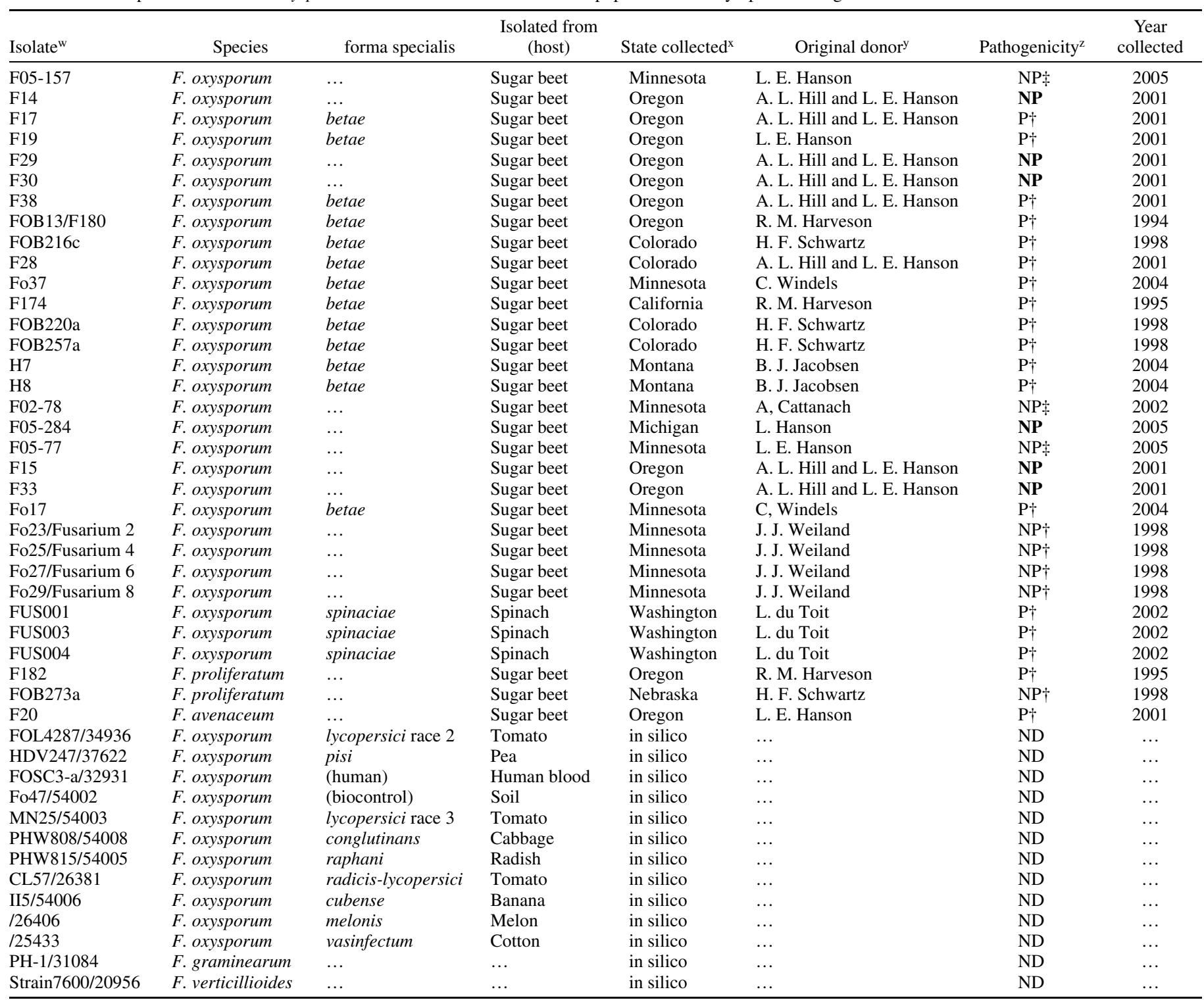

${ }^{\mathrm{w}}$ Isolate or strain name. Isolate name followed by original donor's name. Last 13 isolates are in silico genomic sequences obtained from the BROAD Institute sequence database with original isolate (or strain name) listed first, followed by the NRRL number.

${ }^{x}$ In silico genomic sequence available from the BROAD Institute Fusarium Comparative database (http://www.broadinstitute.org/annotation/genome/ fusarium_group/MultiHome.html).

${ }^{y}$ Current institution of isolate donors: L. E. Hanson, United States Department of Agriculture-Agricultural Research Service (USDA-ARS), East Lansing, MI, 48824; A. L. Hill, Ohio State University, Columbus 43210; R. M. Harveson, University of Nebraska, Scottsbluff 69361; H. F. Schwartz, Colorado State University, Fort Collins 80523; C. Windels, University of Minnesota, Crookston 56716; B. J. Jacobsen, Montana State University, Bozeman 59717; A. Cattanach, American Crystal Sugar Company, Moorhead, MN, 56560; John J. Weiland, USDA-ARS, Fargo, ND, 58102; Lindsey du Toit, Washington State University, Mount Vernon.

${ }^{\mathrm{z}}$ Pathogenicity to sugar beet as determined by $\dagger=$ Hill et al. (27) and $\ddagger=$ Webb et al. (81). Pathogenicity determinations indicated in bold are reported in this article. $\mathrm{NP}=$ nonpathogen, $\mathrm{P}=$ pathogen, and $\mathrm{ND}=$ not determined. 
erating a phylogentic tree using MrBayes performed as described above. Phylogenetic data for Sge1, PelD, and Prtl can be found at TreeBASE under study IDS number 13754.

Population structure analysis. The population structure of the isolates was performed for two data sets (or groups). Each group was defined by organizing isolates into populations based on designation of clade or pathogenicity. The first group, based on clade designation, was determined for each isolate by using the phylogenetic analysis of the reference gene Tefl- $\alpha$ and assignment into one of four populations (A, B, C, or outgroup [OG]), as described by Hill et al. (27). All sequences for Fusarium spp. downloaded from the BROAD Institute were included in the clade group analysis. The second group, pathogenicity, was based on known pathogenicity to sugar beet, where isolates were assigned as either a pathogen or nonpathogen based on pathogenicity testing (Table 1). Sequences for the Fusarium spp. downloaded from the BROAD Institute were not included in this analysis because pathogenicity to sugar beet is unknown.

Analysis of population structure was performed using Arlequin 3.5.1.3 (12). Each of the 13 genes independently, as well as a concatenated gene sequence with all 13 genes for each isolate sequentially concatenated end to end, was used as "haplotypic" input data. The two groups, clade and pathogenicity, were analyzed separately for all 13 genes, as well as the concatenated gene sequence. For each group, standard molecular diversity indices were determined and included total number of loci, total number of polymorphic loci, total number of usable loci, allele frequencies, and expected heterozygosity of loci. The total amount of differentiation among the groups was evaluated using this pairwise distance matrix in a global hierarchical analysis of molecular variance (AMOVA) using 1,023 permutations (82) and a significance level of $P$ value $\leq 0.01$. Tamura and Nei's distance model was used to calculate a pairwise Euclidean squared genetic distance matrix of fixation statistics $(F s t)$ between population of a group and between isolates of a group using 100 permutations (77). Population pairwise genetic distance analysis was also performed using Arlequin, by computing the isolate pairwise Fst matrix for each population of a group (e.g., A by B, B by OG, and so on) to a linearized distance between population using the Tamura and Nei's distance metric with 110 permutations and a significance level of $P$ value $\leq 0.01$. Negative $F s t$ values were interpreted as zero.

\section{RESULTS}

Presence or absence of putative effector genes. Of the 13 genes investigated, six were present in all $F$. oxysporum isolates from sugar beet (Fmk1, Fowl, PelA, Rhol, Snfl, and Ste12), and seven were dispersed within the $F$. oxysporum population from sugar beet (Pda1, PelD, Pep1, Prt1, Sge1, Sixl, and Six6). The number of alleles varied from gene to gene not only within the sugar beet $F$. oxysporum population but also among the in silico sequences representing the other Fusarium isolates. For example, Six6 had 3 alleles, all of which were 468 bp in size, while Ste 12 had 26 alleles, all of which were 1,618 bp in size (Table 3).

In our population of $F$. oxysporum from sugar beet, one isolate amplified a homolog of the Sixl gene (Fo37) (Table 3). Fo37 is pathogenic to sugar beet; therefore, it has been classified as $F$. oxysporum f. sp. betae. The Sixl allele amplified from Fo37 (Sixl-a) had 78.8\% PWI to the Sixl gene of F. oxysporum f. sp. lycopersici race 2 (FOL4287). The Sixl allele found in the genome of $F$. oxysporum f. sp. lycopersici race 3 isolate (MN25, Sixl-f) shares $99.8 \%$ PWI to the allele found in FOL4287. Six 1 alleles were also found in the genomic sequences of $F$. oxysporum f. sp. pisi (HDV247), F. oxysporum f. sp. conglutinans (PHW808), F. oxysporum f. sp. melonis (NRRL26406), and F. oxysporum $\mathrm{f}$. sp. cubense (II5) (Table 3). Collectively, the alleles from these isolates showed $74.6 \%$ PWI to the $F$. oxysporum f. sp. lycopersici allele from FOL4287. PCR amplification of the Six6 gene did not occur from any of the $F$. oxysporum isolates from sugar beet; however, sequences for Six6 were found in $F$. oxysporum f. sp. lycopercisi race 3 (MN25), $F$. oxysporum f. sp. melonis (NRRL26406), and F. oxysporum f. sp. cubense (II5), which had a combined $80.2 \%$ PWI to the allele from FOL4287 (Table 3).

TABLE 2. Polymerase chain reaction primers for amplification of targeted pathogenicity genes

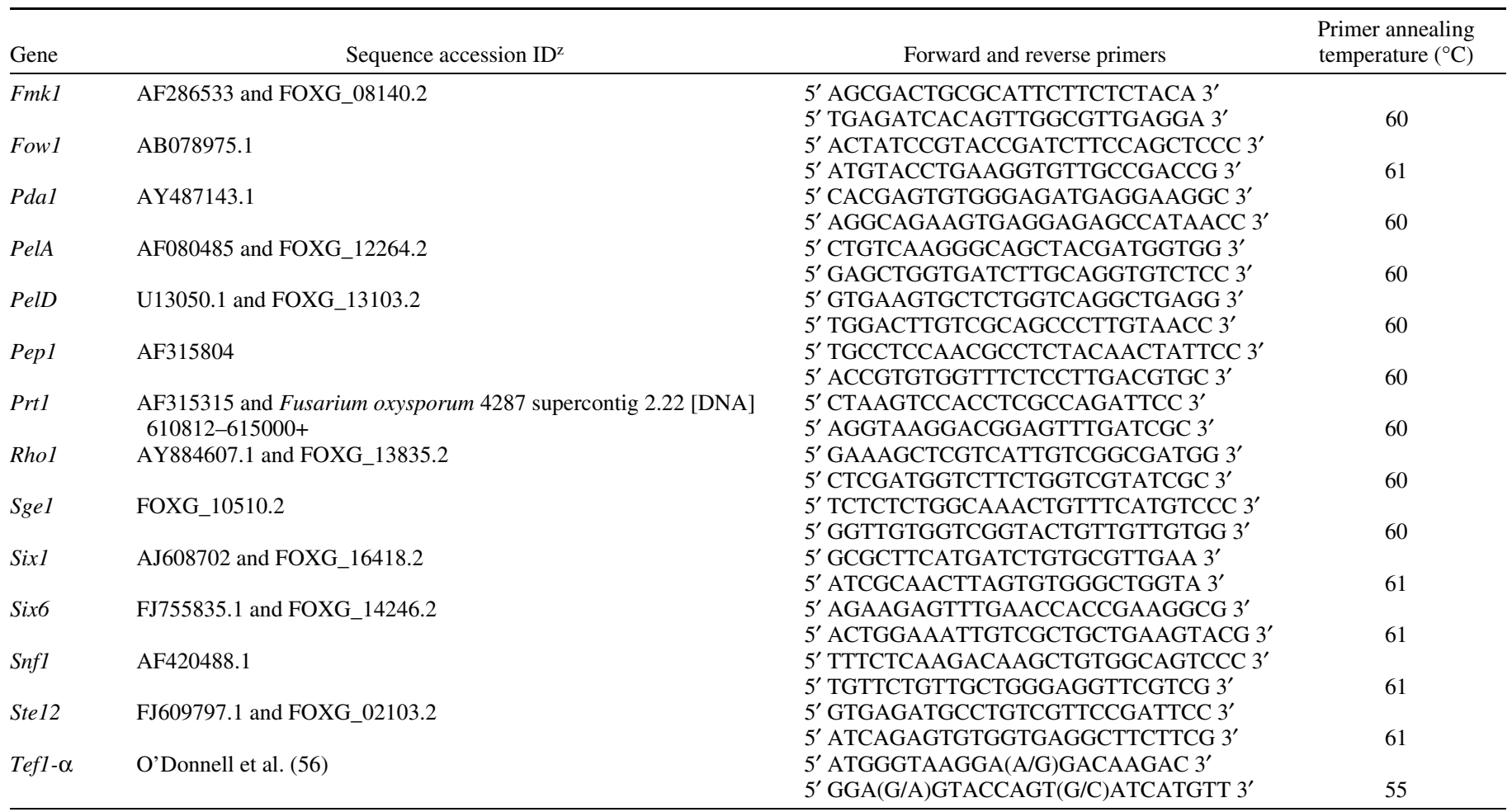

\footnotetext{
${ }^{\mathrm{z}}$ Reference gene sequences for design of primers obtained from National Center for Biotechnology Information (NCBI) database or the BROAD Institute
} Fusarium Comparative Genome database. NCBI accession numbers or BROAD identifications are shown. 
Another gene of interest was the pisatin demethylase (Pdal) gene, which was amplified from 14 of the $F$. oxysporum isolates from sugar beet and found in 3 of the in silico isolates in the BROAD Institute database (Table 3). PWI for all alleles of the Pdal gene was $96 \%$ represented by an $\approx 569$-bp sequence, with three exons (97\% PWI) and two introns where the majority of variability was observed (65 and 67\% PWI, respectively; data not shown). None of the sugar beet $F$. oxysporum alleles of Pdal shared sequence identity to the allele that was obtained from the $F$. oxysporum f. sp. pisi isolate included in this study (HDV247) (Table 3). However, allele Pdal-a, which was found in several of the $F$. oxysporum isolates from sugar beet, was $100 \%$ identical to the previously characterized FoPdal gene from the F. oxysporum f. sp. pisi isolate T415 (6). This allele was found in all pathogenic isolates but was not in the nonpathogenic isolates of clade A.
Amplicons and their nucleotide sequences were obtained from all sugar beet $F$. oxysporum isolates for Fmk1, Fowl, PelA, Rhol, Snfl, and Ste12 genes, although there was allelic diversity in the sequences (Table 3), not all of which caused a change to the predicted amino acid sequence. For example, although Fmkl showed some diversity in synonymous mutations at the nucleotide level, all alleles, except for alleles amplified from the $F$. avenaceum isolate (F20) and the genomic sequence from F. graminearum (PH-1) (data not shown), had the same putative amino acid sequence.

Population structure. Results from AMOVA showed that the Fst values were significant for more genes when analyzed by clade than by pathogenicity (Fig. 1). Fmkl, Fowl, PelA, Rhol, Sge1, Snf1, and Ste12 had Fst values that were significant when analyzed by clade, and PelD and Prtl had significant Fst values when analyzed by pathogenicity (Fig. 1). The Fst value for the

TABLE 3. Allele designation and population indices for sample genes from a population of Fusarium oxysporum (outgroup [OG]) isolates from sugar beet ${ }^{\mathrm{u}}$

\begin{tabular}{|c|c|c|c|c|c|c|c|c|c|c|c|c|c|c|c|}
\hline Isolate & $\mathrm{CI}^{\mathrm{v}}$ & Fmk1 & Fow1 & Pda1 & PelA & PelD & Pep1 & Prt1 & Rho1 & Sge1 & Six 1 & Six6 & Snf1 & Ste12 & Clade $^{\mathrm{w}}$ \\
\hline F05-157 & $\mathrm{a}$ & $\mathrm{a}$ & $\mathrm{a}$ & $\mathrm{a}$ & $\mathrm{a}$ & $\ldots$ & $\ldots$ & $\ldots$ & $\mathrm{a}$ & $\mathrm{a}$ & $\ldots$ & $\ldots$ & $\mathrm{a}$ & $\mathrm{a}$ & A \\
\hline F14 & $\mathrm{b}$ & $\mathrm{a}$ & $\mathrm{b}$ & $\ldots$ & $\mathrm{a}$ & $\ldots$ & $\ldots$ & $\ldots$ & $\mathrm{b}$ & $\mathrm{a}$ & $\ldots$ & $\ldots$ & $\mathrm{a}$ & $\mathrm{b}$ & A \\
\hline F17 & $\mathrm{c}$ & $\mathrm{a}$ & $\mathrm{a}$ & $\mathrm{a}$ & $\mathrm{a}$ & $\ldots$ & $b^{*}$ & $\mathrm{a}$ & $\mathrm{a}$ & $\mathrm{a}$ & $\ldots$ & $\ldots$ & $\mathrm{a}$ & $\mathrm{c}$ & A \\
\hline F19 & $\mathrm{d}$ & $\mathrm{a}$ & $\mathrm{a}$ & $\mathrm{a}$ & $\mathrm{a}$ & $\ldots$ & $a^{*}$ & $\mathrm{a}$ & $\mathrm{a}$ & $\mathrm{a}$ & $\ldots$ & $\ldots$ & $\mathrm{a}$ & $\mathrm{c}$ & $\mathrm{A}$ \\
\hline F29 & $\mathrm{e}$ & a & $\mathrm{c}$ & $\ldots$ & $\mathrm{a}$ & $\ldots$ & $\ldots$ & $\mathrm{b}$ & $\mathrm{b}$ & $\mathrm{a}$ & $\ldots$ & $\ldots$ & b & $\mathrm{c}$ & A \\
\hline F30 & $\mathrm{f}$ & $\mathrm{a}$ & $\mathrm{d}$ & $\ldots$ & $\mathrm{a}$ & $\ldots$ & $\ldots$ & $\mathrm{b}$ & $\mathrm{b}$ & $\mathrm{a}$ & $\ldots$ & $\ldots$ & $\mathrm{b}$ & $\mathrm{c}$ & A \\
\hline F38 & $\mathrm{g}$ & a & a & $\mathrm{a}$ & $\mathrm{a}$ & $\ldots$ & $b^{*}$ & $\mathrm{a}$ & $\mathrm{a}$ & $\mathrm{a}$ & $\ldots$ & $\ldots$ & $\mathrm{a}$ & $\mathrm{d}$ & A \\
\hline FOB13/F180 & $\mathrm{c}$ & $\mathrm{a}$ & a & $\mathrm{a}$ & $\mathrm{a}$ & $\ldots$ & $b^{*}$ & $\mathrm{a}$ & $\mathrm{a}$ & $\mathrm{a}$ & $\ldots$ & $\ldots$ & $\mathrm{a}$ & $\mathrm{c}$ & A \\
\hline FOB216c & $\mathrm{h}$ & $\mathrm{a}$ & $\mathrm{a}$ & $\mathrm{a}$ & $\mathrm{b}$ & $\ldots$ & $\ldots$ & $\mathrm{b}$ & $\mathrm{a}$ & $\mathrm{a}$ & $\ldots$ & $\ldots$ & $\mathrm{a}$ & d & A \\
\hline F28 & $\mathrm{i}$ & $\mathrm{b}$ & e & $\ldots$ & $\mathrm{c}$ & $\ldots$ & $\ldots$ & $\ldots$ & $\mathrm{c}$ & $\ldots$ & $\ldots$ & $\ldots$ & $\mathrm{c}$ & $\mathrm{f}$ & B \\
\hline Fo37 & $\mathrm{j}$ & $\mathrm{c}$ & $\mathrm{f}$ & $\ldots$ & $\mathrm{d}$ & $\ldots$ & $\ldots$ & $\mathrm{b}$ & $\mathrm{d}$ & $\ldots$ & $\mathrm{a}$ & $\ldots$ & d & $\mathrm{g}$ & B \\
\hline F174 & $\mathrm{k}$ & b & e & $\ldots$ & $\mathrm{c}$ & $\ldots$ & $\ldots$ & $\mathrm{c}$ & $\mathrm{c}$ & $\ldots$ & $\ldots$ & $\ldots$ & $\mathrm{c}$ & $\mathrm{h}$ & B \\
\hline FOB220a & $\mathrm{m}$ & $\mathrm{c}$ & $\mathrm{f}$ & $\ldots$ & $\mathrm{d}$ & $\ldots$ & $\ldots$ & $\mathrm{b}$ & $\mathrm{d}$ & $\ldots$ & $\ldots$ & $\ldots$ & d & $\mathrm{g}$ & B \\
\hline FOB257a & $\mathrm{n}$ & $\mathrm{e}$ & $\mathrm{h}$ & $\ldots$ & $\mathrm{f}$ & $\mathrm{b}$ & $\ldots$ & $\mathrm{d}$ & $\mathrm{f}$ & $\mathrm{b}$ & $\ldots$ & $\ldots$ & $f$ & $\mathrm{j}$ & B \\
\hline $\mathrm{H} 7$ & $\mathrm{~m}$ & $\mathrm{c}$ & $\mathrm{f}$ & $\ldots$ & $\mathrm{d}$ & $\ldots$ & $\ldots$ & $\mathrm{b}$ & $\mathrm{d}$ & $\ldots$ & $\ldots$ & $\ldots$ & d & $\mathrm{g}$ & B \\
\hline H8 & $\mathrm{p}$ & c & $\mathrm{f}$ & $\ldots$ & $\mathrm{a}$ & $\ldots$ & $\ldots$ & $\mathrm{b}$ & $\mathrm{d}$ & $\ldots$ & $\ldots$ & $\ldots$ & $\mathrm{d}$ & $\mathrm{g}$ & B \\
\hline F02-78 & $\mathrm{q}$ & $\mathrm{g}$ & $\mathrm{i}$ & $b^{*}$ & $\mathrm{~g}$ & $\mathrm{c}$ & $\ldots$ & $\mathrm{e}$ & $\mathrm{g}$ & $\mathrm{c}$ & $\ldots$ & $\ldots$ & $\mathrm{g}$ & 1 & $\mathrm{C}$ \\
\hline F05-284 & $\mathrm{r}$ & $\mathrm{h}$ & $\mathrm{j}$ & $\ldots$ & $\mathrm{h}$ & $\mathrm{d}$ & $\ldots$ & $\ldots$ & $\mathrm{h}$ & $\mathrm{d}$ & $\ldots$ & $\ldots$ & $\mathrm{h}$ & $\mathrm{m}$ & $\mathrm{C}$ \\
\hline F05-77 & s & $\mathrm{e}$ & $\mathrm{h}$ & $\ldots$ & $\mathrm{f}$ & $\mathrm{d}$ & $c^{*}$ & $\mathrm{f}$ & $\mathrm{i}$ & $\mathrm{b}$ & $\ldots$ & $\ldots$ & $\mathrm{i}$ & $\mathrm{j}$ & $\mathrm{C}$ \\
\hline F15 & $\mathrm{t}$ & $\mathrm{i}$ & $\mathrm{k}$ & $\mathrm{c}^{*}$ & $\mathrm{i}$ & $\mathrm{e}$ & $d^{*}$ & $\mathrm{~g}$ & $\mathrm{j}$ & $\mathrm{e}$ & $\ldots$ & $\ldots$ & $\mathrm{j}$ & $\mathrm{n}$ & $\mathrm{C}$ \\
\hline F33 & $\mathrm{g}$ & e & $\mathrm{j}$ & $\ldots$ & $\mathrm{h}$ & $\mathrm{d}$ & $\ldots$ & $\ldots$ & $\mathrm{k}$ & $\mathrm{d}$ & $\ldots$ & $\ldots$ & $\mathrm{h}$ & $\mathrm{m}$ & $\mathrm{C}$ \\
\hline Fo17 & $\mathrm{v}$ & $\mathrm{e}$ & 1 & $\mathrm{a}$ & $\mathrm{f}$ & $\mathrm{d}$ & $\mathrm{e}^{*}$ & $\mathrm{f}$ & $\mathrm{f}$ & $\mathrm{d}$ & $\ldots$ & $\ldots$ & $\mathrm{k}$ & $\mathrm{j}$ & $\mathrm{C}$ \\
\hline Fo23/Fusarium 2 & $\mathrm{w}$ & $\mathrm{j}$ & $\mathrm{m}$ & $\mathrm{d}$ & $\mathrm{b}$ & $\mathrm{f}$ & $c^{*}$ & $\mathrm{f}$ & 1 & $\mathrm{f}$ & $\ldots$ & $\ldots$ & 1 & o & $\mathrm{C}$ \\
\hline Fo25/Fusarium 4 & $\mathrm{x}$ & $\mathrm{j}$ & $\mathrm{m}$ & $\ldots$ & $\mathrm{j}$ & $\mathrm{f}$ & $c^{*}$ & $\mathrm{f}$ & $\mathrm{m}$ & $f$ & $\ldots$ & $\ldots$ & 1 & $\mathrm{p}$ & $\mathrm{C}$ \\
\hline Fo27/Fusarium 6 & $\mathrm{y}$ & $\mathrm{e}$ & 1 & $\ldots$ & $\mathrm{k}$ & $\mathrm{d}$ & $\mathrm{f}$ & $\mathrm{f}$ & $\mathrm{f}$ & d & $\ldots$ & $\ldots$ & $\mathrm{m}$ & $\mathrm{j}$ & $\mathrm{C}$ \\
\hline Fo29/Fusarium 8 & $\mathrm{Z}$ & $\mathrm{j}$ & $\mathrm{m}$ & $\mathrm{d}$ & $\mathrm{d}$ & f & $c^{*}$ & $\mathrm{f}$ & 1 & $\mathrm{f}$ & $\ldots$ & $\ldots$ & 1 & $q$ & $\mathrm{C}$ \\
\hline FUS001 & al & $\mathrm{i}$ & $\mathrm{n}$ & $\mathrm{g}^{*}$ & $\mathrm{~m}$ & $\mathrm{p}$ & $d^{*}$ & 1 & $\mathrm{~s}$ & $\mathrm{k}$ & $\ldots$ & $\ldots$ & $\mathrm{n}$ & $\mathrm{y}$ & $\mathrm{C}$ \\
\hline FUS003 & am & $\mathrm{i}$ & $\mathrm{n}$ & $\mathrm{g}^{*}$ & $\mathrm{~m}$ & $\mathrm{p}$ & & 1 & $\mathrm{~s}$ & 1 & $\ldots$ & $\ldots$ & $\mathrm{n}$ & $\mathrm{y}$ & $\mathrm{C}$ \\
\hline FUS004 & al & i & $\mathrm{n}$ & $\mathrm{g} *$ & $\mathrm{~m}$ & $\mathrm{p}$ & $d^{*}$ & 1 & s & $\mathrm{k}$ & $\ldots$ & $\ldots$ & $\mathrm{n}$ & $\mathrm{y}$ & $\mathrm{C}$ \\
\hline F182 & 1 & $\mathrm{~d}$ & $\mathrm{~g}$ & $\ldots$ & $\mathrm{e}$ & $\mathrm{a}$ & $\ldots$ & $\ldots$ & $\mathrm{e}$ & $\ldots$ & $\ldots$ & $\ldots$ & $\mathrm{e}$ & $\mathrm{i}$ & OG \\
\hline Fob273a & o & $\mathrm{f}$ & $\mathrm{g}$ & $\ldots$ & $\mathrm{e}$ & $\ldots$ & $\ldots$ & $\ldots$ & e & $\ldots$ & $\ldots$ & $\ldots$ & $\mathrm{e}$ & $\mathrm{k}$ & $\mathrm{OG}$ \\
\hline F20 & an & $\mathrm{r}$ & $\mathrm{r}$ & $\ldots$ & $\mathrm{r}$ & $\mathrm{q}$ & $\ldots$ & $\ldots$ & $\mathrm{t}$ & $\ldots$ & $\ldots$ & $\ldots$ & $\mathrm{r}$ & $\mathrm{z}$ & OG \\
\hline FOL4287/34936 & $\mathrm{ag}$ & $\mathrm{p}$ & $\mathrm{q}$ & $\ldots$ & o & $\mathrm{m}$ & $\mathrm{g} *$ & i & $\mathrm{r}$ & $\mathrm{j}$ & $\mathrm{d}$ & $\mathrm{b}$ & $\mathrm{k}$ & w & $\mathrm{C}$ \\
\hline HDV247/37622 & $\mathrm{ae}$ & $\mathrm{n}$ & $\mathrm{n}$ & $\mathrm{f}$ & $\mathrm{m}$ & $\mathrm{k}$ & $\mathrm{h}$ & $\mathrm{h}$ & $\mathrm{p}$ & $\mathrm{c}$ & $\mathrm{b}$ & $\ldots$ & g & $\mathrm{u}$ & $\mathrm{C}$ \\
\hline FOSC3-a/32931 & $\mathrm{ad}$ & $\mathrm{m}$ & o & $\ldots$ & 1 & $\mathrm{j}$ & $\ldots$ & $\ldots$ & $\mathrm{o}$ & $\mathrm{h}$ & $\ldots$ & $\ldots$ & $\mathrm{p}$ & $\mathrm{t}$ & $\mathrm{C}$ \\
\hline Fo47/54002 & ac & e & $\mathrm{j}$ & $\ldots$ & $\mathrm{h}$ & $\mathrm{i}$ & $\ldots$ & $\ldots$ & $\mathrm{n}$ & $\mathrm{d}$ & $\ldots$ & $\ldots$ & o & $\mathrm{m}$ & $\mathrm{C}$ \\
\hline MN25/54003 & ai & $\mathrm{e}$ & $\mathrm{j}$ & $\ldots$ & $\mathrm{h}$ & $\mathrm{i}$ & $\ldots$ & $\mathrm{k}$ & $\mathrm{n}$ & $\mathrm{d}$ & $\mathrm{f}$ & $\mathrm{b}$ & $\mathrm{h}$ & $\mathrm{m}$ & $\mathrm{C}$ \\
\hline PHW808/54008 & aj & $q$ & $\mathrm{i}$ & $b^{*}$ & $\mathrm{~g}$ & $\mathrm{n}$ & $\ldots$ & $\ldots$ & $\mathrm{g}$ & $\mathrm{c}$ & $\mathrm{g}$ & $\ldots$ & $\mathrm{g}$ & $\mathrm{u}$ & $\mathrm{C}$ \\
\hline PHW815/54005 & $\mathrm{ak}$ & $\mathrm{n}$ & $\mathrm{n}$ & $\ldots$ & $\mathrm{q}$ & o & $\mathrm{i}$ & $\ldots$ & $\mathrm{p}$ & $\mathrm{c}$ & $\ldots$ & $\ldots$ & $\mathrm{g}$ & $\mathrm{u}$ & $\mathrm{C}$ \\
\hline CL57/26381 & $a b$ & 1 & $\mathrm{j}$ & $\ldots$ & $\mathrm{h}$ & $\mathrm{h}$ & $\mathrm{j}$ & $\mathrm{f}$ & $\mathrm{n}$ & $\mathrm{d}$ & $\ldots$ & $\ldots$ & $\mathrm{i}$ & s & $\mathrm{C}$ \\
\hline II5/54006 & af & o & $\mathrm{p}$ & $\ldots$ & $\mathrm{n}$ & 1 & $\ldots$ & $\ldots$ & $\mathrm{q}$ & $\mathrm{i}$ & $\mathrm{c}$ & $\mathrm{c}$ & $q$ & $\mathrm{v}$ & $\mathrm{C}$ \\
\hline$/ 26406$ & $\mathrm{ah}$ & $\mathrm{p}$ & $\mathrm{q}$ & $\ldots$ & $\mathrm{p}$ & $\mathrm{m}$ & $\ldots$ & $\mathrm{j}$ & $r$ & $\mathrm{j}$ & e & $\mathrm{a}$ & $\mathrm{k}$ & $\mathrm{x}$ & $\mathrm{C}$ \\
\hline$/ 25433$ & aa & $\mathrm{k}$ & $\mathrm{n}$ & $\mathrm{e}^{*}$ & $\mathrm{i}$ & $\mathrm{g}$ & $\ldots$ & $\ldots$ & $\mathrm{j}$ & $\mathrm{g}$ & $\ldots$ & $\ldots$ & $\mathrm{n}$ & $\mathrm{r}$ & $\mathrm{C}$ \\
\hline PH-1/31084 & ao & $\mathrm{s}$ & $\mathrm{s}$ & $\ldots$ & $\mathrm{s}$ & $\mathrm{r}$ & $\ldots$ & $\ldots$ & $\mathrm{u}$ & $\mathrm{n}$ & $\ldots$ & $\ldots$ & $\mathrm{s}$ & aa & OG \\
\hline Strain7600/20956 & ap & $\mathrm{t}$ & $\mathrm{t}$ & $\ldots$ & $\mathrm{t}$ & $\mathrm{s}$ & $\ldots$ & $\ldots$ & $\mathrm{v}$ & $\mathrm{m}$ & $\ldots$ & $\ldots$ & $\mathrm{t}$ & $\mathrm{ab}$ & OG \\
\hline Alleles $(n)^{\mathrm{x}}$ & 42 & 20 & 20 & 7 & 20 & 19 & 10 & 12 & 22 & 14 & 7 & 3 & 20 & 28 & $\ldots$ \\
\hline PWI $(\%)^{\mathrm{y}}$ & 75.2 & 96.6 & 97 & 96 & 95.3 & 93.8 & 71.5 & 97.2 & 94.9 & 96.9 & 77.1 & 80.2 & 96.8 & 96.4 & $\ldots$ \\
\hline Loci/length $(\mathrm{bp})^{\mathrm{z}}$ & 10,014 & 605 & 779 & 569 & 485 & 582 & 838 & 1,133 & 681 & 675 & 469 & 468 & 631 & 1,618 & $\ldots$ \\
\hline
\end{tabular}

u Presence of a gene is listed by the nucleotide allele (alphabetic) designation; * indicates predicted mutant allele (i.e., a premature stop codon).

${ }^{v}$ Concatenated idiomorph (CI) of the gene sequences of each gene in each isolate.

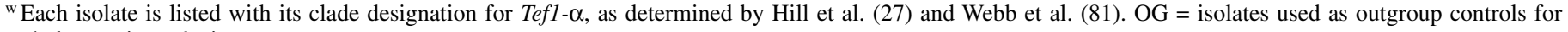
phylogenetic analysis.

$x$ Total number of nucleotide alleles in the population for each gene.

y Pairwise identity (PWI) was determined across all isolates for each gene.

${ }^{\mathrm{z}}$ Length in base pairs for each gene. 
concatenated gene sequence was significant for both groups. Genes that did not have significant $F s t$ values for either clade or pathogenicity were Pdal, Pep1, Sixl, and Six6.

All genes with significant $F s t$ values for clade were conserved across all Fusarium isolates included in the study, except for Sge1. The allelic patterns and phylogenetic analysis of these genes demonstrated topologies and genealogical concordance similar to that of Tefl- $\alpha$, supporting the clade designations laid out by Hill et al. (27) (Table 3). Most of the genes found to be significant had Fst values near 0.5 (Fig. 1A), indicating that variance components portioned roughly equally among and between populations compared with the total variance (data not shown). Sgel demonstrated a higher Fst value compared with the Fst values for the other genes that were significant by clade (Fig. 1A). Sgel was dispersed across the population and showed discordance between its gene genealogy and the phylogenetic organization described by Tefl- $\alpha$. A large proportion of the variance for Sgel was partitioned among the clades, and was explained mostly by an absence of Sgel alleles in clade B isolates (Fig. 2). Additionally, all clade A isolates contained only one Sgel allele (Table 3 ).

The pairwise genetic distance $F s t$ values indicated that clade A has a greater genetic distance when compared with each of the other clades (Fig. 3). Fmk1, Fow1, PelA, Rho1, Snfl, and Ste12, as well as the concatenated gene sequence, were found to have significant $F$ st values in all pairwise clade comparisons (Fig. 3). The Fst values for three genes (Sge1, PelD, and Pda1) showed differing significance depending on specific pairwise clade comparisons. Sgel was found to not be significant for comparison between clades B and $\mathrm{C}$ and clades B and OG, although the Fst values were high for all other clade comparisons (Fig. 3). For example, the Sge1 Fst value for the pairwise comparisons between clades $\mathrm{A}$ and $\mathrm{B}$ and clades $\mathrm{A}$ and $\mathrm{OG}$ approached the maximum of 1 (Fig. 3) and, in this case, Sgel was absent in all but one isolate (FOB257a) of clade B (Table 3). The Fst values for PelD were significant for the pairwise comparison between clades $\mathrm{C}$ and $\mathrm{OG}$, and Pdal was significant for the pairwise comparisons between clades A and C. Prtl was not significant for any of pairwise clade comparisons (Fig. 3).

Putative effector genes, when analyzed by pathogenicity in AMOVA, had an average $F s t$ value of $\approx 0.26$ (Fig. 1B) and lower variance partitioning among the populations compared with the total variance observed. Two of the genes tested (PelD and Prt1) had significant $F s t$ values when analyzed by pathogenicity and demonstrated higher relative $F$ st values $(0.42$ and 0.35 , respectively) (Fig. 1B). Both PelD and Prtl were genealogically dispersed across the $F$. oxysporum population from sugar beet. Prt1 was present in more pathogenic (to sugar beet) F. oxysporum isolates than nonpathogens, as opposed to PelD, which was found mostly in nonpathogenic isolates (Fig. 4; Table 3). Despite being significant for pathogenicity, PelD alleles were absent from more than one clade; in this case, both clade A and clade B isolates. However, the remaining alleles of PelD in clades $\mathrm{C}$ and $\mathrm{OG}$ were not monopolized by any one allele and the variance partitioning

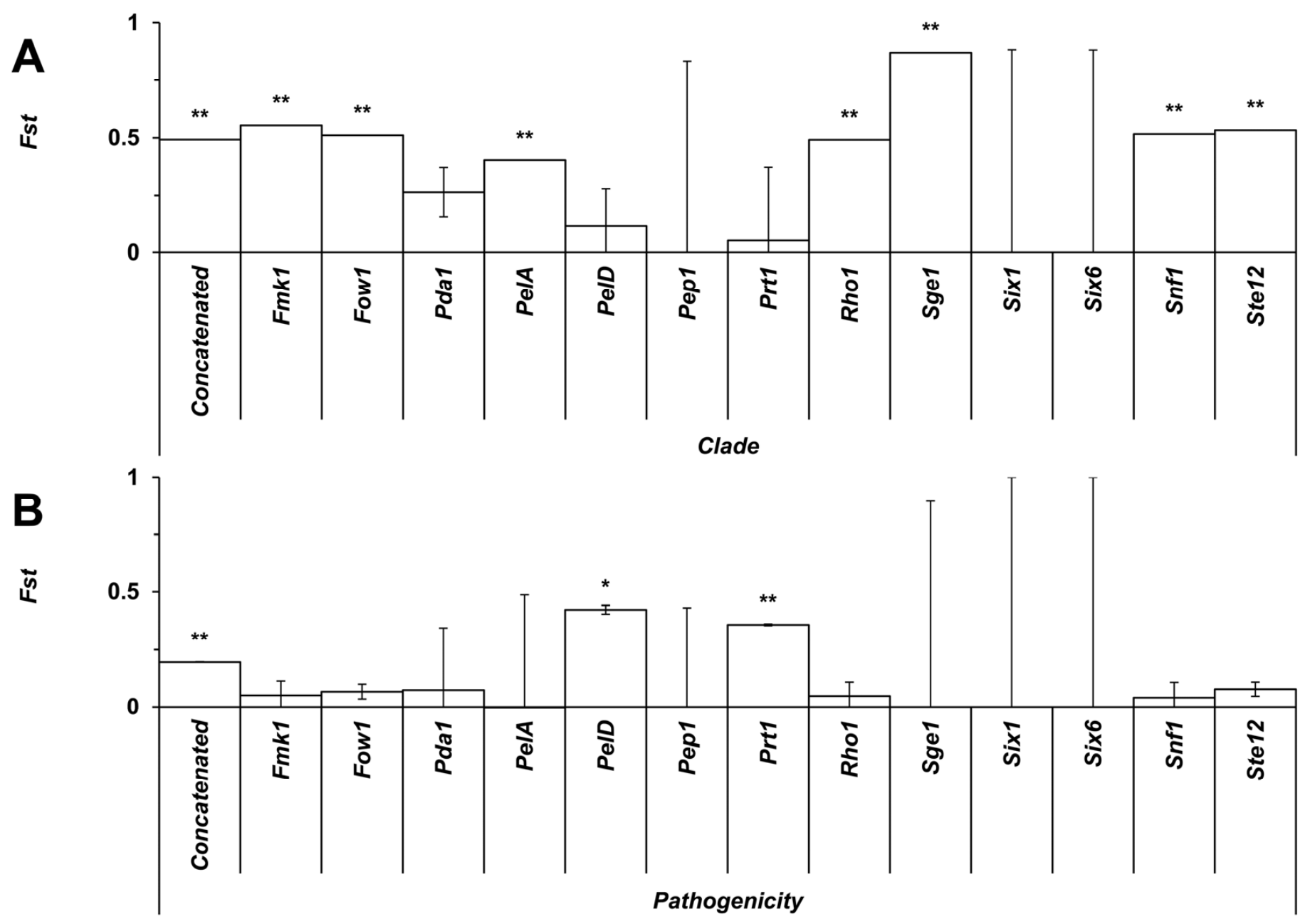

Fig. 1. Analysis of molecular variance fixation index $(F s t)$ values for the concatenated gene sequence and each pathogenicity gene when describing clade and pathogenicity, respectively, in a Fusarium oxysporum population from sugar beet. A, Fst values $\pm P$ values analyzed by clade. In silico genome sequences were included in the analysis. B, Fst $\pm P$ value analyzed by pathogenicity. In silico genome sequences were not included in the analysis. Error bars indicate the amount of variation in $F s t$ value for each gene. $P$ values for significant genes are indicated as follows: $* *$ and $*=P<0.001$ and 0.01 , respectively. 


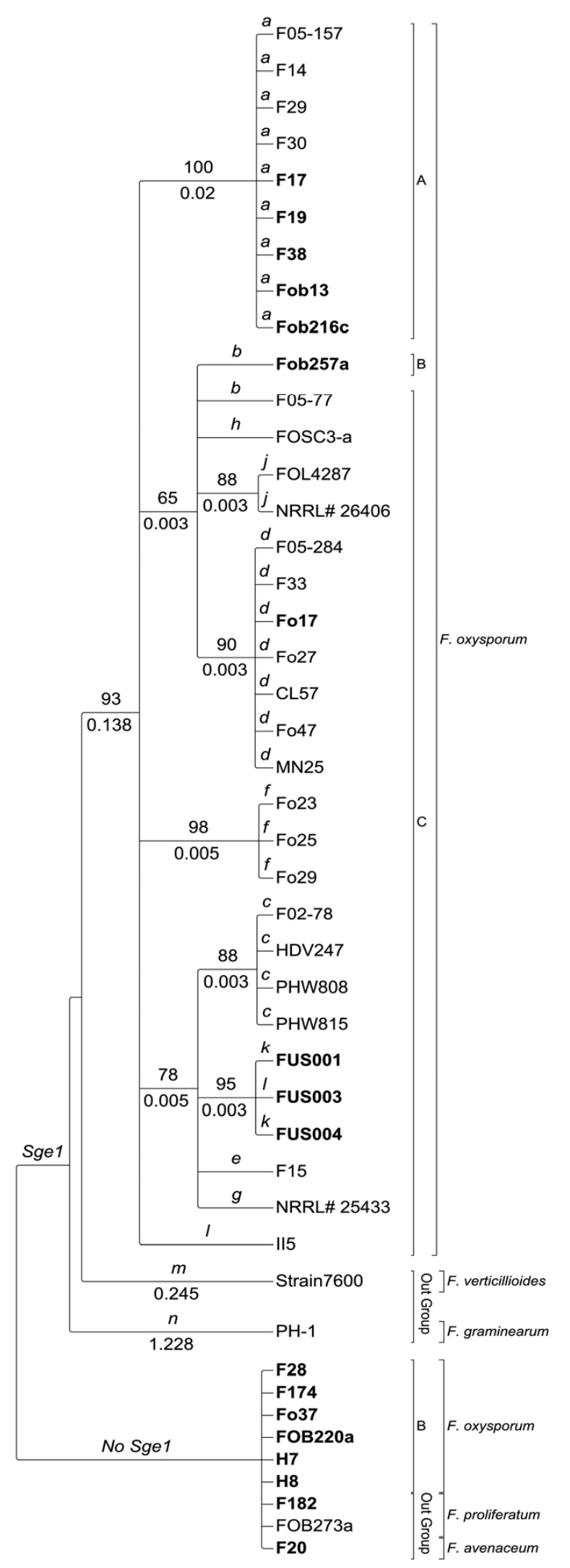

Fig. 2. Phylogenetic trees for Sgel that showed significant fixation index (Fst) values by clade. Bayesian posterior-probabilities $(\times 100)>50$ are shown above the branch and branch lengths (substitutions per site) below. Allele designations (lowercase) for each gene are labeled above the branch. Isolates with pathogenicity to sugar beet are in bold. Clade designation (A, B, C, or outgroup [OG]) and species are labeled for each isolate. Fusarium graminearium (PH-1) was used to root the tree for Sge1. Isolates where a gene was not amplified were not included in the Bayesian analysis but are shown as a separate branch for clarity. remained low among the population (Fig. 4; Table 3). Prt1, while genealogically dispersed in all clades, primarily associated with pathogenic isolates (Fig. 5; Table 3).

\section{DISCUSSION}

Most studies characterizing the population structure of fungal pathogens, including $F$. oxysporum, have utilized single homologous gene markers that are found in many fungal species (76). An increasing number of studies are utilizing more than a single gene to characterize and describe populations of fungal species $(36,41$, 48,65). In Fusarium spp., O'Donnell et al. (54) used multiple gene markers to characterize the species complex of Gibberella fujikuroi. However, rapid diagnostic techniques are still mostly unavailable for identifying all strains of $F$. oxysporum to formae speciales (61). Although conserved gene markers have been useful in characterizing the $F$. oxysporum $\mathrm{f}$. sp. betae population into phylogenetic clades, they have been ineffective in differentiating pathogenic from nonpathogenic isolates $(27,81)$. Several researchers have started to use loci that are under balancing selection (such as effector genes) to describe fungal populations, some of which can also be effective in identifying pathogenic F. oxysporum $(43,72,75)$.

In this study, we utilized 13 genes (Fmkl, Fowl, Pdal, PelA, PelD, Pep1, Prt1, Rho1, Sge1, Six1, Six6, Snf1, and Ste12), all but one of which have been previously described to contribute to pathogenicity of fungal plant pathogens $(9,21,29,33,47,49,58$, $62,66,67,79)$, to describe a population of $F$. oxysporum from sugar beet into phylogenetic clades and, potentially, be used to identify pathogenic isolates of $F$. oxysporum $\mathrm{f}$. sp. betae. Of the genes investigated, six were present in all $F$. oxysporum isolates from sugar beet (Fmkl, Fowl, PelA, Rhol, Snfl, and Ste12) and seven were found to be dispersed within the $F$. oxysporum population (Pda1, PelD, Pep1, Prt1, Sge1, Six1, and SixO). Of those found in all F. oxysporum isolates from sugar beet, Fmkl, Fowl, PelA, Rhol, Sge1, Snfl, and Ste12 had Fst values that were significant in describing clade designations while PelD, and Prtl had Fst values significant for describing pathogenicity to sugar beet. Although we were unable to identify a single marker that would allow us to clearly differentiate all pathogenic $F$. oxysporum $\mathrm{f}$. sp. betae strains from nonpathogenic isolates, we were able to identify putative genes that may be contributing (or linked) to pathogenicity to sugar beet.

Within the population of $F$. oxysporum isolated from sugar beet, six conserved genes (Fmkl, Fowl, PelA, Rhol, Snfl, and Ste12) had $F s t$ values that were significant for describing differences between the phylogenetic clade designations previously reported $(27,81)$. As described, the presence of effector genes across the larger sample of not just $F$. oxysporum strains but also other Fusarium spp. supports the idea of shared common origins and raises the possibility of pleiotropic functions for many of these genes, not just in pathogenicity or host specificity $(10,58$, $66,68,83)$. However, a larger sample of isolates representing the broader diversity of the entire Fusarium species complex would be needed to assess specific relationships or potential functions. Because our results support the phylogenetic relationships previously reported by others $(27,81)$ and do not provide any additional insights into the genetic diversity of the population of F. oxysporum from sugar beet, we suggest that the use of a single conserved gene $(T E F 1 \alpha)$ would adequately describe the phylogenetic relationships in the broader $F$. oxysporum species complex, as suggested by Webb et al. (81).

Two genes, PelD and Prt1, demonstrated significant genetic differences for analysis by pathogenicity within the sugar beet $F$. oxysporum population. PelD was present in $16 \mathrm{~F}$. oxysporum isolates from sugar beet and had 19 differing alleles in the entire population tested. The PelD sequences in our study had a total of $\approx 94 \%$ PWI to the F. solani PelD (NCBI: U13050) (data not 
shown). Despite having a dispersed nature in the population, PelD was present almost exclusively in clade $\mathrm{C}$ and one isolate from clade B (Fob257a), as well as from F. proliferatum, F. graminearum, and $F$. verticillioides. It appears that the absence of PelD primarily is associated with pathogenicity to sugar beet, and its exclusion from the majority of pathogenic $F$. oxysporum f. sp. betae isolates (mostly in clades A and B) suggests that this gene does not contribute to pathogenicity on sugar beet. The PelD and PelA genes investigated in this article are members of a four-gene pectate lyase family found in $F$. solani $(16,18,19,31,67)$. Presence of PelB and PelC paralogs in the sugar beet $F$. oxysporum population was not investigated but should be investigated in the future.

The other gene that demonstrated significant genetic differences for pathogenicity was Prt1, which is orthologous to the $F$. solani ORF4 and is similar to the restless $A c$-like transposon from T. inflatum $(21,38)$. Prt1 was present as a genealogically dispersed gene within the $F$. oxysporum population from sugar beet, and the majority of those isolates containing Prtl were pathogenic to sugar beet (Fig. 5; Table 3). Contribution of Prt1, if any, to pathogenicity of sugar beet is unknown and remains an avenue of future research. Its use as a marker for pathogenicity has strong research appeal, particularly due to its association with a previously described pathogenicity island (the $P E P$ gene cluster) in the $F$. solani species complex, which contains genes required for causing disease in pea (Pisum sativum L.) (21). Additionally, in prokaryotes and in some fungi, pathogenicity islands are on traditionally mobile elements and, in the case of Fusarium spp., on supernumerary chromosomes that likely are transmitted horizontally and carry a number of disease-specific pathogenicity determinants $(21,45,53,63)$. Whether these mobile elements are playing a role in the population of $F$. oxysporum f. sp. betae and pathogenicity to sugar beet is unknown but, based on some of our results, should continue to be evaluated.

Several other genes were of general interest due to their previous use in describing other formae speciales of $F$. oxysporum. Lievens et al. (43) used the presence of several Six genes to discriminate isolates pathogenic to tomato and, therefore, to the formae speciales of $F$. oxysporum f. sp. lycopersici. All but one of the isolates from the sugar beet $F$. oxysporum population amplified a Sixl homolog and none of them contained the Six6 gene. However, the Sixl allele that was amplified from Fo37 (a pathogenic isolate from sugar beet) only had a 78.8\% PWI to the Sixl gene found in $F$. oxysporum f. sp. lycopersici race 2 (FOL4287). Because of the low PWI identity to the Sixl gene from FOL4287, we predict that isolate Fo37 is unlikely to be pathogenic to tomato, nor is it a member of $F$. oxysporum $\mathrm{f}$. sp. lycopersici. However, pathogenicity testing on tomato has not been done to confirm this hypothesis but could be done in future experiments.
The Pdal gene has been reported to be important for some fungal pathogens, including $F$. oxysporum $\mathrm{f}$. sp. pisi, to degrade the phytoalexin pisatin and contributes to its pathogenicity to pea $(6,79)$. Pdal has been used in previous phylogenetic analysis to identify strains of $F$. solani and $F$. oxysporum that cause disease of pea (51). We found that this gene was amplified from 14 of the $F$. oxysporum isolates from sugar beet; however, only one allele, Pdal-a, had $100 \%$ identity to the previously characterized FoPdal gene from the F. oxysporum f. sp. pisi isolate T415 (data not shown) (6). Pdal-a was found in all sugar-beet-pathogenic isolates but not in the nonpathogenic isolates of clade A. Coleman et al. (6) found that only particular alleles of $P d a$ were able to degrade pisatin or contributed to pathogenicity. It is unknown whether the isolates in our study that contain the Pdal-a allele are able to degrade pisatin or if they are cross-pathogenic to pea but this should be tested in future experiments. Another possibility is that sugar beet has been reported to produce two phytoalexins, betagarin and betavulgarin, in response to pathogen infection $(20,35,46,64)$. Betavulgarin $\left(\mathrm{C}_{17} \mathrm{H}_{12} \mathrm{O}_{6}\right)$ is an isoflavone similar to pisatin $\left(\mathrm{C}_{17} \mathrm{H}_{14-16} \mathrm{O}_{6}\right)(8,35,64)$ and future research could be undertaken to determine whether Pdal alleles found in our population are potentially interacting with and degrading these phytoalexins found in sugar beet and, therefore, contributing to pathogenicity to sugar beet.

A particularly interesting sequence result from this study was the discovery of Pepl alleles (Pep1- $a$ and Pepl-b) which contain a putative Folyt hAT type II transposable element (TE) (15) inserted into the coding sequence of the Pepl genes of all but one pathogenic isolate of clade A. The TE was $316 \mathrm{bp}$ long and contained inverted terminal repeat sequences characteristic of known $h A T$ TE's (data not shown). How this putative TE relates to hAT type II TEs still needs to be investigated but, because this sequence was primarily in pathogenic isolates from clade $\mathrm{A}$, it makes this a valuable avenue of future investigation as a potential identifying marker.

Several of the genes investigated did not result in amplification under our experimental conditions. Although the primer annealing sites were selected based on regions with highly conserved sequence, we concede that there is a risk in drawing the conclusion that those genes are not present in those isolates. It is possible that there have been mutations at primer annealing sites, an intron has made the gene too large to be amplified, or even the presence of homologous sequences elsewhere in the genome are competing for primer annealing. Future work, including Southern analysis on current gene selections, as well as including additional reported effector factors not tested here, are ongoing in order to resolve many of these possibilities.

Rapid and reliable methods to differentiate pathogenic isolates of $F$. oxysporum f. sp. betae from nonpathogenic isolates of

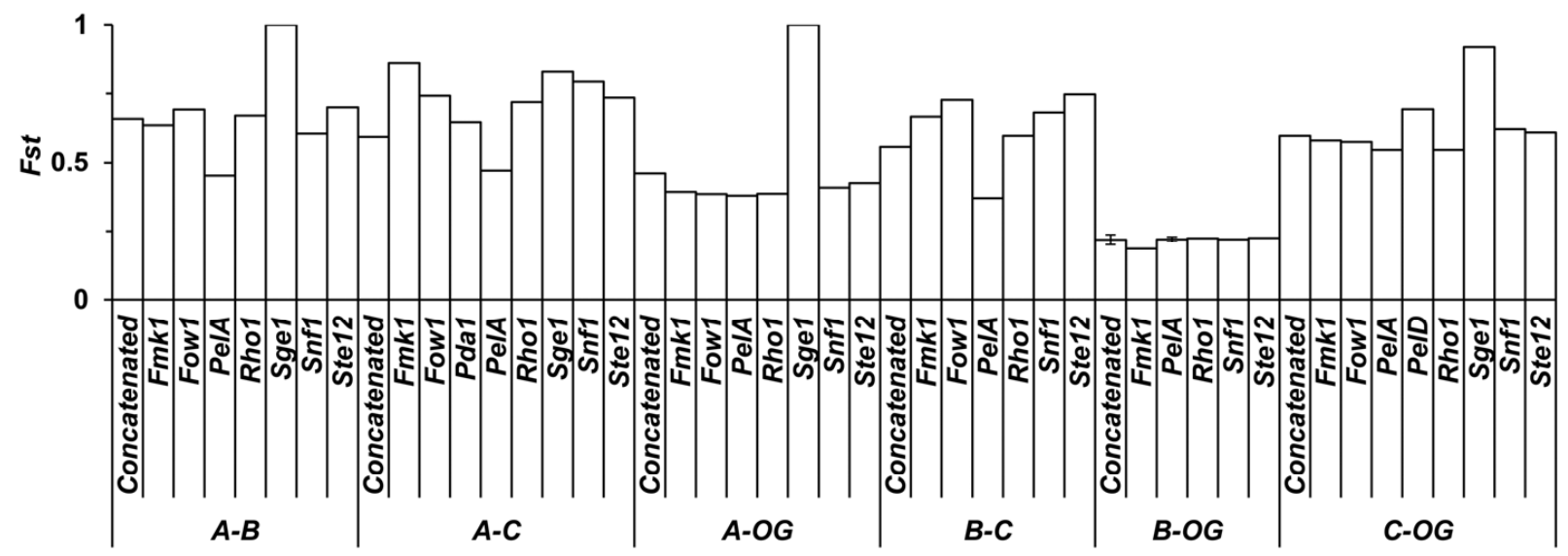

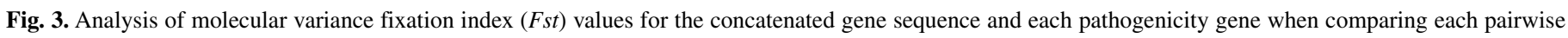
clade designation. Fst values $\pm P$ values for each pairwise clade comparison. Only genes with significant $F s t$ values are shown $(P<0.01,110$ permutations $)$. 


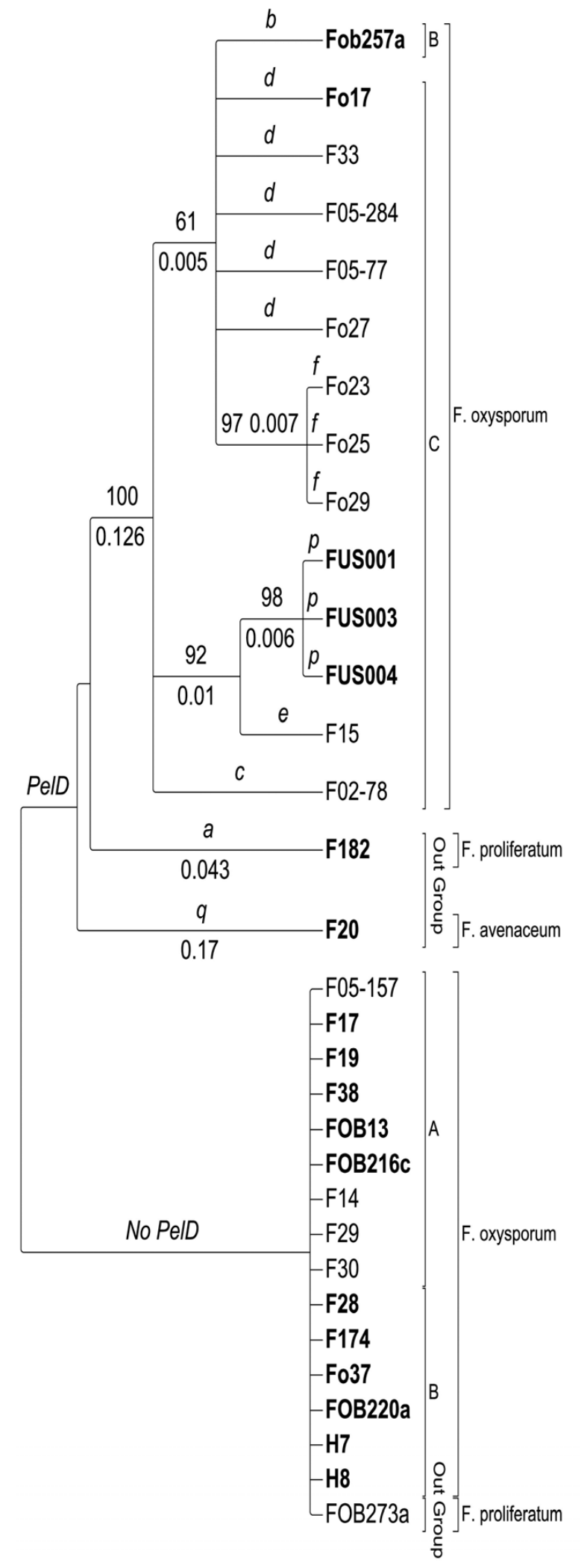

Fig. 4. Phylogenetic tree for PelD that showed significant fixation index $(F s t)$ values by pathogenicity. Bayesian posterior-probabilities $(\times 100)>50$ are shown above the branch and branch lengths (substitutions per site) below. Allele designations (lowercase) for each gene are labeled above the branch. Isolates with pathogenicity to sugar beet are in bold. Clade designation (A, B, $\mathrm{C}$, or outgroup) and species are labeled for each isolate. Fusarium avenaceum (F20) was used to root the tree for PelD. Isolates where a gene was not amplified were not included in the Bayesian analysis but are shown as a separate branch for clarity.

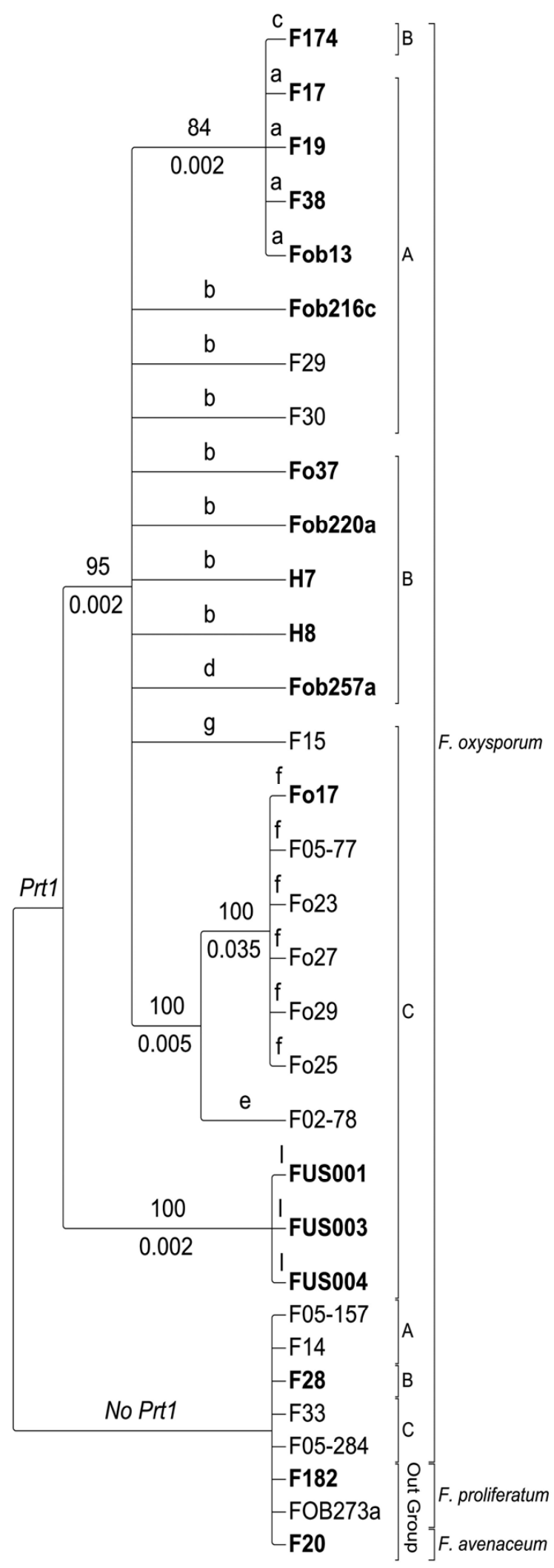

Fig. 5. Phylogenetic tree for Prtl that showed significant fixation index (Fst) values by pathogenicity. Bayesian posterior-probabilities $(\times 100)>50$ are shown above the branch and branch lengths (substitutions per site) below. Allele designations (lowercase) for each gene are labeled above the branch. Isolates with pathogenicity to sugar beet are in bold. Clade designation (A, B, $\mathrm{C}$, or outgroup) and species are labeled for each isolate. Fusarium oxysporum isolates FUS001, FUS003, and FUS004 were used to root the tree for Prt1. Isolates where a gene was not amplified were not included in the Bayesian analysis but are shown as a separate branch for clarity. 
F. oxysporum are currently unavailable to sugar beet researchers and producers. Utilizing gene genealogies of several previously described effector genes (Fmkl, Fowl, Pdal, PelA, PelD, Pepl, Rhol, Sge1, Sixl, Six6, Snf1, and Ste12), we found that many were not only significant in their ability to correlate with the phylogenetic relationships of a population of $F$. oxysporum from sugar beet but two were also significant in being associated with pathogenicity to sugar beet. How these genes can be used to characterize our population against the broader $F$. oxysporum species complex should be investigated further; however, preliminary analysis indicates that using a multilocus approach utilizing putative effector genes may be useful in differentiating pathogenic F. oxysporum f. sp. betae. This research also identified potential genes that may contribute to the pathogenicity of $F$. oxysporum f. sp. betae to sugar beet, and experiments to follow up with these findings will be performed in the future. Although only a subset of potential effector genes was investigated on a small sample of isolates from the sugar beet $F$. oxysporum population, we predict that expanding the numbers of both will clarify some of the preliminary relationships identified.

\section{ACKNOWLEDGMENTS}

Additional funding for this project was provided by the Beet Sugar Development Foundation. We thank C. Richards and P. Reeves from the Plant Germplasm Preservation Research Unit at the United States Department of Agriculture-Agricultural Research Service National Center for Genetics Resource Preservation for assistance in data analysis. Mention of trade names or commercial products in this article is solely for the purpose of providing specific information and does not imply recommendation or endorsement by the United States Department of Agriculture (USDA). USDA is an equal opportunity provider and employer.

\section{LITERATURE CITED}

1. Appel, D. J., and Gordon, T. R. 1996. Relationships among pathogenic and nonpathogenic isolates of Fusarium oxysporum based on the partial sequence of the intergenic spacer region of the ribosomal DNA. Mol. Plant-Microbe Interact. 2:125-138.

2. Armstrong, G. M., and Armstrong, J. K. 1981. Formae speciales and races of Fusarium oxysporum causing wilt diseases. Pages 391-399 in: Fusarium: Diseases, Biology, and Taxonomy. P. E. Nelson, T. A. Toussoun, and R. J. Cook, eds. The Pennsylvania State University Press, University Park.

3. Baayen, R. P., O’Donnell, K., Bonants, P. J. M., Cigelnik, E., Kroon, L. P. N., Roebroeck, R. J. A., and Waalwijk, C. 2000. Gene genealogies and AFLP analyses in the Fusarium oxysporum complex identify monophyletic and nonmonophyletic formae speciales causing wilt and rot diseases. Phytopathology 90:891-900.

4. Campbell, L. G., Fugate, K. K., and Niehaus, W. S. 2011. Fusarium yellows affects postharvest respiration rate, sucrose concentration and invert sugar in sugarbeet. J. Sugar Beet Res. 48:17-39.

5. Chisholm, S. T., Coaker, G., Day, B., and Staskawicz, B. J. 2006. Hostmicrobe interactions: shaping the evolution of the plant immune response. Cell 124:803-814.

6. Coleman, J. J., Wasmann, C. C., Usami, T., White, G. J., Temporini, E., McCluskey, K., and VanEtten, H. D. 2011. Characterization of the gene encoding pisatin demethylase (FoPDA1) in Fusarium oxysporum. Mol. Plant-Microbe Interact. 24:1482-1491.

7. Cramer, R. A., Byrne, P. F., Brick, M. A., Panella, L., Wickliffe, E., and Schwartz, H. F. 2003. Characterization of Fusarium oxysporum isolates from common bean and sugar beet using pathogenicity assays and randomamplified polymorphic DNA markers. J. Phytopathol. 151:352-360.

8. Cruickshank, I. A. M., and Perrin, D. R. 1960. Isolation of a phytolexin from Pisum sativum L. Nature 187:799-780.

9. Di Pietro, A., Garcia-Maceira, F. L., Meglecz, E., and Roncero, M. I. G. 2001. A MAP kinase of the vascular wilt fungus Fusarium oxysporum is essential for root penetration and pathogenesis. Mol. Microbiol. 39:1140-1152.

10. Di Pietro, A., Madrid, M. P., Caracuel, Z., Delgado-Jarana, J., and Roncerom, M. 2003. Fusarium oxysporum: exploring the molecular arsenal of a vascular wilt fungus. Mol. Plant Pathol. 4:315-325.

11. Elias, K. S., Schneider, R. W., and Lear, M. M. 1991. Analysis of vegetative compatibility groups in nonpathogenic populations of Fusarium oxysporum isolated from symptomless tomato roots. Can. J. Bot. 69:2089-2094.
12. Excoffier, L., and Lischer, H. E. 2010. Arlequin suite ver. 3.5: a new series of programs to perform population genetics analyses under Linux and Windows. Mol. Ecol. Resour. 10:564-567.

13. Fravel, D., Olivain, C., and Alabouvette, C. 2003. Fusarium oxysporum and its biocontrol. New Phytol. 157:493-502.

14. Fong, Y. K., Anuar, S., Lim, H. P., Tham, F. Y., and Sanderson, F. R. 2000. A modified filter paper technique for long-term preservation of some fungal cultures. Mycologist 14:127-130.

15. Gómez-Gómez, E., Anaya, N., Roncero, M. I. G., and Hera, C. 1999. Folyt1, a new member of the $h A T$ family, is active in the genome of the plant pathogen Fusarium oxysporum. Fungal Genet. Biol. 27:67-76.

16. González-Candelas, L., and Kolattukudy, P. E. 1992. Isolation and analysis of a novel inducible pectate lyase gene from the phytopathogenic fungus Fusarium solani f. sp. pisi (Nectria haematococca, mating population VI). J. Bacteriol. 174:6343-6349.

17. Gordon, T. R., and Martyn, R. D. 1997. The evolutionary biology of Fusarium oxysporum. Annu. Rev. Phytopathol. 35:111-128.

18. Guo, W., González-Candelas, L., and Kolattukudy, P. E. 1995. Cloning of a novel constitutively expressed pectate lyase gene pelB from Fusarium solani f. sp. pisi (Nectria haematococca, mating type VI) and characterization of the gene product expressed in Pichia pastoris. J. Bacteriol. 177:7070-7077.

19. Guo, W., González-Candelas, L., and Kolattukudy, P. E. 1996. Identification of a novel pelD gene expressed uniquely in planta by Fusarium solani f. sp. pisi (Nectria haematococca, mating type VI) and characterization of its protein product as an endo-pectate lyase. Arch. Biochem. Biophys. 332:305-312.

20. Halloin, J. M. 1994. Localization of phenolic compounds in crowns and roots of healthy and Rhizoctonia solani-infected sugar beets. Plant Sci. 99:223-228.

21. Han, Y., Liu, X., Benny, U., Kistler, H. C., and VanEtten, H. D. 2001. Genes determining pathogenicity to pea are clustered on a supernumerary chromosome in the fungal plant pathogen Nectria haematococca. Plant $\mathrm{J}$. 25:305-314.

22. Hanson, L. E., and Hill, A. L. 2004. Fusarium species causing Fusarium yellows of sugarbeet. J. Sugar Beet Res. 41:163-178.

23. Hanson, L. E., and Jacobsen, B. J. 2006. Beet root-rot inducing isolates of Fusarium oxysporum from Colorado and Montana. Plant Dis. 90:247.

24. Hanson, L. E., and Jacobsen, B. J. 2009. Fusarium yellows. Pages 28-29 in: Compendium of Beet Diseases and Pests. R. M. Harveson, L. E. Hanson, and G. L. Hein, eds. American Phytopathological Society Press, St. Paul, MN.

25. Harveson, R. M., and Rush, C. M. 1997. Genetic variation among Fusarium oxysporum isolates from sugarbeet as determined by vegetative compatibility. Plant Dis. 81:85-88.

26. Harveson, R. M., and Rush, C. M. 1998. Characterization of Fusarium root rot isolates from sugar beet by growth and virulence at different temperatures and irrigation regimes. Plant Dis. 82:1039-1042.

27. Hill, A. L., Reeves, P. A., Larson, R. L., Fenwick, A. L., Hanson, L. E., and Panella, L. 2011. Genetic variability among isolates of Fusarium oxysporum from sugar beet. Plant Pathol. 60:496-505.

28. Hogenhout, S. A., Van der Hoorn, R. A. L., Terauchi, R., and Kamoun, S. 2009. Emerging concepts in effector biology of plant-associated organisms. Mol. Plant-Microbe Interact. 22:115-122.

29. Houterman, P. M., Speijer, D., Dekker, H. L., de Koster, C. G., Cornelissen, B. J. C., and Rep, M. 2007. The mixed xylem sap proteome of Fusarium oxysporum-infected tomato plants. Mol. Plant Pathol. 8:215-221.

30. Huelsenbeck, J. P., and Ronquist, F. 2001. MRBAYES: Bayesian inference of phylogenetic trees. Bioinformatics 17:754-755.

31. Huertas-González, M. D., Ruiz-Roldán, M. C., García Maceira, F. I., Roncero, M. I., and Di Pietro, A. 1999. Cloning and characterization of pll encoding an in planta-secreted pectate lyase of Fusarium oxysporum. Curr. Genet. 35:36-40.

32. Idnurm, A., and Howlett, B. J. 2001. Pathogenicity genes of phytopathogenic fungi. Mol. Plant Pathol. 2:241-255.

33. Inoue, I., Namiki, F., and Tsuge, T. 2002. Plant colonization by the vascular wilt fungus Fusarium oxysporum requires Fow1, a gene encoding a mitochondrial protein. Plant Cell 14:1869-1883.

34. Jones, J. D., and Dangl, J. L. 2006. The plant immune system. Nature 444:323-329.

35. Johnson, G., Maag, D. D., Johnson, D. K., and Thomas, R. D. 1976. The possible role of phytolexins in the resistance of sugarbeet (Beta vulgaris) to Cercospora beticola. Physiol. Plant Pathol. 8:225-230.

36. Kasuga, T., Taylor, J., and White, T. J. 1999. Phylogenetic relationships of varieties and geographical groups of the human pathogenic fungus, Histoplasma capsulatum. J. Clin. Microbiol. 37:653-663.

37. Kearse, M., Moir, R., Wilson, A., Stones-Havas, S., Cheung, M., Sturrock, S., Buxton, S., Cooper, A., Markowitz, S., Duran, C., Thierer, T., Ashton, B., Meintjes, P., and Drummond, A. 2012. Geneious Basic: an integrated and extendable desktop software platform for the organization and 
analysis of sequence data. Bioinformatics 28:1647-1649.

38. Kempken, F., and Kück, U. 1996. restless, an active Ac-like transposon from the fungus Tolypocladium inflatum: structure, expression, and alternative RNA splicing. Mol. Cell. Biol. 16:6563-6572.

39. Kistler, H. C. 1997. Genetic diversity in the plant-pathogen fungus Fusarium oxysporum. Phytopathology 87:474-479.

40. Larkin, M. A., Blackshields, G., Brown, N. P., Chenna, R., McGettigan, P. A., McWilliam, H., Valentin, F., Wallace, I. M., Wilm, A., Lopez, R., Thompson, J. D., Gibson, T. J., and Higgins, D. G. 2007. Clustal W and Clustal X version 2.0. Bioinformatics 23:2947-2948.

41. Leavitt, S. D., Esslinger, T. L., Spribille, T., Divakar, P. K., and Thorsten Lumbsch, H. 2013. Multilocus phylogeny of the lichen-forming fungal genus Melanohalea (Parmeliaceae, Ascomycota): insights on diversity, distributions, and a comparison of species tree and concatenated topologies. Mol. Phylogenet. Evol. 66:138-152.

42. Leslie, J. F., and Summerell, B. A. 2006. The Fusarium Laboratory Manual. Blackwell Publishing, Ames, IA.

43. Lievens, B., Houterman, P. M., and Rep, M. 2009. Effector gene screening allows unambiguous identification of Fusarium oxysporum $\mathrm{f}$. sp. lycopersici races and discrimination from other formae speciales. FEMS Microbiol. Lett. 300:201-215

44. Lievens, B., Rep, M., and Thomma, B. P. 2008. Recent developments in the molecular discrimination of formae speciales of Fusarium oxysporum. Pest Manage. Sci. 64:781-788.

45. Ma, L. J., van der Does, H. C., Borkovich, K. A., Coleman, J. J., Daboussi, M.-J., Di Pietro, A., Dufresne, M., Freitag, M., Grabherr, M., Henrissat, B., Houterman, P. M., Kang, S., Shim, W.-B., Woloshuk, C., Xie, X., Xu, J.-R., Antoniw, J., Baker, S. E., Bluhm, B. H., Breakspear, A., Brown, D. W., Butchko, R. A. E., Chapman, S., Coulson, R., Coutinho, P. M. Danchin, E. G. J., Diener, A., Gale, L. R., Gardiner, D. M., Goff, S., Hammond-Kosack, K. E., Hilburn, K., Hua-Van, A., Jonkers, W., Kazan, K., Kodira, C. D., Koehrsen, M., Kumar, L., Lee, Y.-H., Li, L., Manners, J. M., Miranda-Saavedra, D., Mukherjee, M., Park, G., Park, J., Park, S.-Y., Proctor, R. H., Regev, A., Ruiz-Roldan, M. C., Sain, D., Sakthikumar, S., Sykes, S., Schwartz, D. C., Turgeon, B. G., Wapinski, I., Yoder, O., Young, S., Zeng, Q., Zhou, S., Galagan, J., Cuomo, C. A., Kistler, H. C., and Rep, M. 2010. Comparative genomics reveals mobile pathogenicity chromosomes in Fusarium. Nature 464:367-373.

46. Martin, S. 1989. Analysis of constitutive and induced phenolics of Beta vulgaris by high performance liquid chromatography. J. Sugar Beet Res. 26:33-39

47. Martinez-Rocha, A. L., Roncero, M. I. G., Lopez-Ramirez, A., Marine, M., Guarro, J., Martinez-Cadena, G., and Di Pietro, A. 2008. Rhol has distinct functions in morphogenesis, cell wall biosynthesis and virulence of Fusarium oxysporum. Cell. Microbiol. 10:1339-1351.

48. McDonald, M. C., Razavi, M., Friesen, T. L., Brunner, P. C., and McDonald, B. A. 2012. Phylogenetic and population genetic analyses of Phaeosphaeria nodorum and its close relatives indicate cryptic species and an origin in the fertile crescent. Fungal Genet. Biol. 49:882-895.

49. Michielse, C., van Wijk, R., Reijnen, L., Manders, E. M. M., Boas, S., Olivain, C., Alabouvette, C., and Rep, M. 2009. The nuclear protein Sge1 of Fusarium oxysporum is required for parasitic growth. PLoS Pathol. 5:e1000637.

50. Michielse, C. B., and Rep, M. 2009. Pathogen profile update: Fusarium oxysporum. Mol. Plant Pathol. 10:311-324.

51. Milani, N. A., Lawrence, D. P., Elizabeth Arnold, A., and Van Etten, H. D. 2012. Origin of pisatin demethylase (PDA) in the genus Fusarium. Fungal Genet. Biol. 49:933-942.

52. Nitschke, E., Nihlgard, M., and Varrelmann, M. 2009. Differentiation of eleven Fusarium spp. isolated from sugar beet, using restriction fragment analysis of a polymerase chain reaction-amplified translation elongation factor $1 \alpha$ gene fragment. Phytopathology 99:921-929.

53. Ochman, H., Lawrence, J. G., and Goisman, E. A. 2000. Lateral gene transfer and the nature of bacterial evolution. Nature 405:299-304.

54. O’Donnell, K., Cigelnik, E., and Nirenberg, H. I. 1998. Molecular systematics and phylogeography of the Gibberella fujikuroi species complex. Mycologia 90:465-493.

55. O’Donnell, K., Gueidan, C., Sink, S., Johnston, P. R., Crous, P. W., Glenn, A., Riley, R., Zitomer, N. C., Colyer, P., Waalwijk, C., van der Lee, T., Moretti, A., Kang, S., Kim, H. S., Geiser, D. M., Juba, J. H., Baayen, R. P., Cromey, M. G., Bithell, S., Sutton, D. A., Skovgaard, K., Ploetz, R., Corby Kistler, H., Elliott, M., Davis, M., and Sarver, B. A. J. 2009. A twolocus DNA sequence database for typing plant and human pathogens within the Fusarium oxysporum species complex. Fungal Genet. Biol. 46:936-948.

56. O’Donnell, K., Kistler, H. C., Cigelnik, E., and Ploetz, R. C. 1998. Multiple evolutionary origins of the fungus causing Panama disease of banana: concordant evidence from nuclear and mitochondrial gene genealogies. Proc. Natl. Acad. Sci. USA 95:2044-2049.

57. Olivain, C., and Alabouvette, C. 1999. Process of tomato root coloni- zation by a pathogenic strain of Fusarium oxysporum f. sp. lycopersici in comparison with a non-pathogenic strain. New Phytol. 141:497-510.

58. Ospina-Giraldo, M. D., Mullins, E., and Kang, S. 2003. Loss of function of the Fusarium oxysporum SNF1 gene reduces virulence on cabbage and Arabidopsis. Curr. Genet. 44:49-57.

59. Peever, T. L., and Milgroom, M. G. 1992. Inheritance of triadimenol resistance in Pyrenophora teres. Phytopathology 82:821-828.

60. Puhalla, J. E. 1985. Classification of strains of Fusarium oxysporum on the basis of vegetative compatibility. Can. J. Bot. 63:179-183.

61. Recorbet, G., Steinberg, C., Olivain, C., Edel, V., Trouvelot, S., DumasGaudot, E., Gianinazzi, S., and Alabouvette, C. 2003. Wanted: pathogenesis-related marker molecules for Fusarium oxysporum. New Phytol. 159:73-92.

62. Rep, M., Houterman, P. M., van der Does, H. C., and Cornelissen, B. J. C. 2005. Fusarium oxysporum evades I-3-mediated resistance without altering the matching avirulence gene. Mol. Plant-Microbe Interact. 18:15-23.

63. Rep, M., and Kistler, H. C. 2010. The genomic organization of plant pathogenicity in Fusarium species. Curr. Opin. Plant Biol. 13:1-7.

64. Richardson, P. M. 1981. Phytoalexin induction in Beta and Spinacia. Biochem. Syst. Ecol. 9:105-107.

65. Rintoul, T. L., Eggertson, Q. A., and Levesque, C. A. 2012. Plant fungal pathogens multigene phylogenetic analysis to delimit new species in fungal plant pathogens. Methods Mol. Biol. 835:549-569.

66. Rispail, N., and Di Pietro, A. 2009. Fusarium oxysporum Ste12 controls invasive growth and virulence downstream of the Fmkl MAPK Cascade. Mol. Plant-Microbe Interact. 22:830-839.

67. Rogers, L. M., Kim, Y.-K., Guo, W., González-Candelas, L., Li, D., and Kolattukudy, P. E. 2000. Requirement for either a host- or pectin- induced pectate lyase for infection of Pisum sativum by Nectria hematococca. Proc. Natl. Acad. Sci. USA 97:9813-9818.

68. Roncero, M., Hera, C., Ruiz-Rubio, M., Maceira, F., Madrid, M., Caracuel, Z., Calero, F., Delgado-Jarana, J., Roldán-Rodríguez, R., Martínez-Rocha, A., Velasco, C., Martín-Urdiroz, J., Córdoba, D., and Di Pietro, A. 2003. Fusarium as a model for studying virulence in soilborne plant pathogens. Physiol. Mol. Plant Pathol. 62:87-98.

69. Rozen, S., and Skaletsky, H. J. 2000. Primer3 on the WWW for general users and for biologist programmers. Pages 365-386 in: Bioinformatics Methods and Protocols: Methods in Molecular Biology. S. Krawetz, and S. Misener, eds. Humana Press, Totowa, NJ.

70. Ruppel, E. G. 1991. Pathogenicity of Fusarium spp. from diseased sugarbeets and variation among sugarbeet isolates of $F$. oxysporum. Plant Dis. 75:486-489

71. Schneider, D. J., and Collmer, A. 2010. Studying plant-pathogen interactions in the genomics era: beyond molecular Koch's postulates to systems biology. Annu. Rev. Phytopathol. 48:457-479.

72. Schurch, S., Linde, C. C., Knogge, W., Jackson, L. F., and McDonald, B. A. 2004. Molecular population genetic analysis differentiates two virulence mechanisms of the fungal avirulence gene NIP1. Mol. PlantMicrobe Interact. 17:1114-1125

73. Snyder, W. C., and Hansen, H. N. 1940. The species concept in Fusarium. Am. J. Bot. 27:64-67.

74. Stewart, D. 1931. Sugar-beet yellows caused by Fusarium conglutinans var. betae. Phytopathology 21:59-70.

75. Stukenbrock, E. H., and McDonald, B. A. 2007. Geographical variation and positive diversifying selection in the host-specific toxin SnToxA. Mol. Plant Pathol. 8:321-332.

76. Stukenbrock, E. H., and McDonald, B. A. 2009. Population genetics for fungal and oomycete effectors involved in gene-for-gene interactions. Mol. Plant-Microbe Interact. 22:371-380.

77. Tamura, K., and Nei, M. 1993. Estimation of the number of nucleotide substitutions in the control region of mitochondrial DNA in humans and chimpanzees. Mol. Biol. Evol. 10:512-526.

78. van der Does, H. C., and Rep, M. 2007. Virulence genes and the evolution of host specificity in plant-pathogenic fungi. Mol. Plant-Microbe Interact. 20:1175-1182.

79. Wasmann, C. C., and VanEtten, H. D. 1996. Transformation-mediated chromosome loss and disruption of a gene for pisatin demethylase decrease the virulence of Nectria haematococca on pea. Mol. PlantMicrobe Interact. 9:793-803.

80. Webb, K. M., Case, A. J., Brick, M. A., Otto, K., and Schwartz, H. F. 2013. Cross pathogenicity and vegetative compatibility of Fusarium oxysporum isolated from sugar beet. Plant Dis. 97:1200-1206.

81. Webb, K. M., Covey, P. A., and Hanson, L. E. 2012. Pathogenic and phylogenetic analysis of Fusarium oxysporum from sugarbeet in Michigan and Minnesota. J. Sugar Beet Res. 49:38-56.

82. Weir, B. S., and Cockerham, C. C. 1984. Estimating F-statistics for the analysis of population structure. Evolution 38:1358-1370.

83. Wong Sak Hoi, J., and Dumas, B. 2010. Ste12 and Ste12-like proteins, fungal transcription factors regulating development and pathogenicity. Eukaryot. Cell. 9:480-485. 